\title{
Mitochondria: pharmacological manipulation of cell death
}

\author{
Lisa Bouchier-Hayes, Lydia Lartigue, and Donald D. Newmeyer
}

La Jolla Institute for Allergy and Immunology, Department of Cellular Immunology, San Diego, California, USA.

\begin{abstract}
Cell death by apoptosis or necrosis is often important in the etiology and treatment of disease. Since mitochondria play important roles in cell death pathways, these organelles are potentially prime targets for therapeutic intervention. Here we discuss the mechanisms through which mitochondria participate in the cell death process and also survey some of the pharmacological approaches that target mitochondria in various ways.
\end{abstract}

\section{Introduction}

Mitochondria are involved in many processes essential for cell survival, including energy production, redox control, calcium homeostasis, and certain metabolic and biosynthetic pathways. In addition, mitochondria often play an essential role in physiological cell death mechanisms. These genetically controlled mitochondrial pathways are often subject to dysfunction. Hence mitochondria can be central players in pathological conditions as diverse as cancer, diabetes, obesity, ischemia/reperfusion injury, and neurodegenerative disorders such as Parkinson and Alzheimer diseases. Research aimed at elucidating the role of mitochondria in cell death has become one of the fastest growing disciplines in biomedicine (1).

\section{Mitochondria and cell death}

The caspases are an apoptosis-related family of proteases that, upon activation, cleave specific substrates, leading to the demise of the cell (2). Although the signaling events upstream of caspases often remain obscure, in general, apoptotic stimuli engage caspases either through death receptor stimulation or through mitochondrial outer membrane permeabilization (MOMP) (Figure 1). With rare exceptions, MOMP leads to cell death even if caspases are inhibited (3). MOMP results in the release of multiple proteins from the mitochondrial intermembrane space (IMS) into the cytosol. This leads to caspase activation in the cytosol, loss of $\Delta \Psi_{\mathrm{m}}$ (mitochondrial membrane potential), cellular ATP depletion, and free radical production (3). One of the released IMS proteins is cytochrome $c$, an important component of the mitochondrial respiratory chain. When translocated into the cytoplasm, cytochrome $c$ stimulates the assembly of a multiprotein complex known as the Apaf-1 apoptosome. Caspase- 9 is recruited to the apoptosome and activated, initiating a cascade of effector caspase activation (4). Other proteins released from the mitochondria during apoptosis include Smac/ DIABLO, endonuclease G (Endo G), apoptosis-inducing factor (AIF), and HtrA2/Omi. Smac promotes caspase activation indirectly by neutralizing the effects of XIAP, a natural caspase inhibitor

Nonstandard abbreviations used: AIF, apoptosis-inducing factor; ANT, adenine nucleotide translocase; $\mathrm{BH}, \mathrm{Bcl}-2$ homology (domain); CsA, cyclosporin A; Cyp D, cyclophilin D; Endo G, endonuclease G; IMS, intermembrane space; MnSOD, manganese superoxide dismutase; MOM, mitochondrial outer membrane; MOMP, MOM permeabilization; PT, permeability transition; PTP, PT pore; VDAC, voltage-dependent anion channel.

Conflict of interest: The authors have declared that no conflict of interest exists.

Citation for this article: J. Clin. Invest. 115:2640-2647 (2005).

doi:10.1172/JCI26274.
$(5,6)$. The apoptotic roles of some IMS proteins remain controversial; a complicating issue is that these proteins may have essential functions in mitochondria whose dysregulation could affect cell survival through action upstream of $\operatorname{MOMP}(7,8)$. Moreover, the release of Endo G and AIF from the mitochondria may require further caspase-independent events subsequent to $\operatorname{MOMP}(9,10)$, such as cleavage of AIF by calpain (11).

\section{Molecular mechanisms of MOMP}

MOMP is thought to be a "point of no return" in the mitochondrial apoptotic pathway (12). As mitochondria are a potential therapeutic target for disorders connected with apoptosis dysregulation, it will be important to gain a detailed understanding of MOMP and its regulation. The mechanisms of MOMP have been controversial (12-19), and there are 2 principal hypotheses: in the first, MOMP is regulated by the Bcl-2 family of proteins, and in the second, by the permeability transition pore (PTP) (Figure 1). The first model considers MOMP as a process that is essentially intrinsic to the outer membrane and requires members of the Bcl-2 family of proteins to promote or prevent the formation of pores. Studies using vesicles formed from isolated mitochondrial outer membranes (MOMs) have shown that Bcl-2-family proteins can regulate the permeability of the MOM in the absence of interior structures of the mitochondria; moreover, many features of this process of membrane permeabilization can be reproduced using defined liposomes and recombinant Bcl-2-family proteins (20). However, these cell-free systems probably do not represent all the complexity of the permeabilization process as it occurs in the native MOM; other proteins of the MOM could modulate or potentiate the function of Bax and Bak. Moreover, the release of specific IMS proteins into the cytoplasm could be influenced by anchorage of these proteins to internal structures or entrapment in mitochondrial cristae (21). Proteins normally involved in mitochondrial fission and fusion may participate in MOMP (reviewed in refs. 3, 13, 22-24). However, this is a controversial topic, made especially challenging by the complex network of protein interactions involved in mitochondrial dynamics. The disruption of any element of this system could have pleiotropic and indirect effects that are difficult to interpret.

The second prominent model for MOMP is based on a phenomenon known as the mitochondrial permeability transition (PT). PT involves the rapid permeabilization of the inner mitochondrial membrane to solutes smaller than $1.5 \mathrm{kDa}$, through formation of the PT pore (PTP). The PTP complex is a "megapore" thought to span the contact sites between the inner and outer mitochondrial 


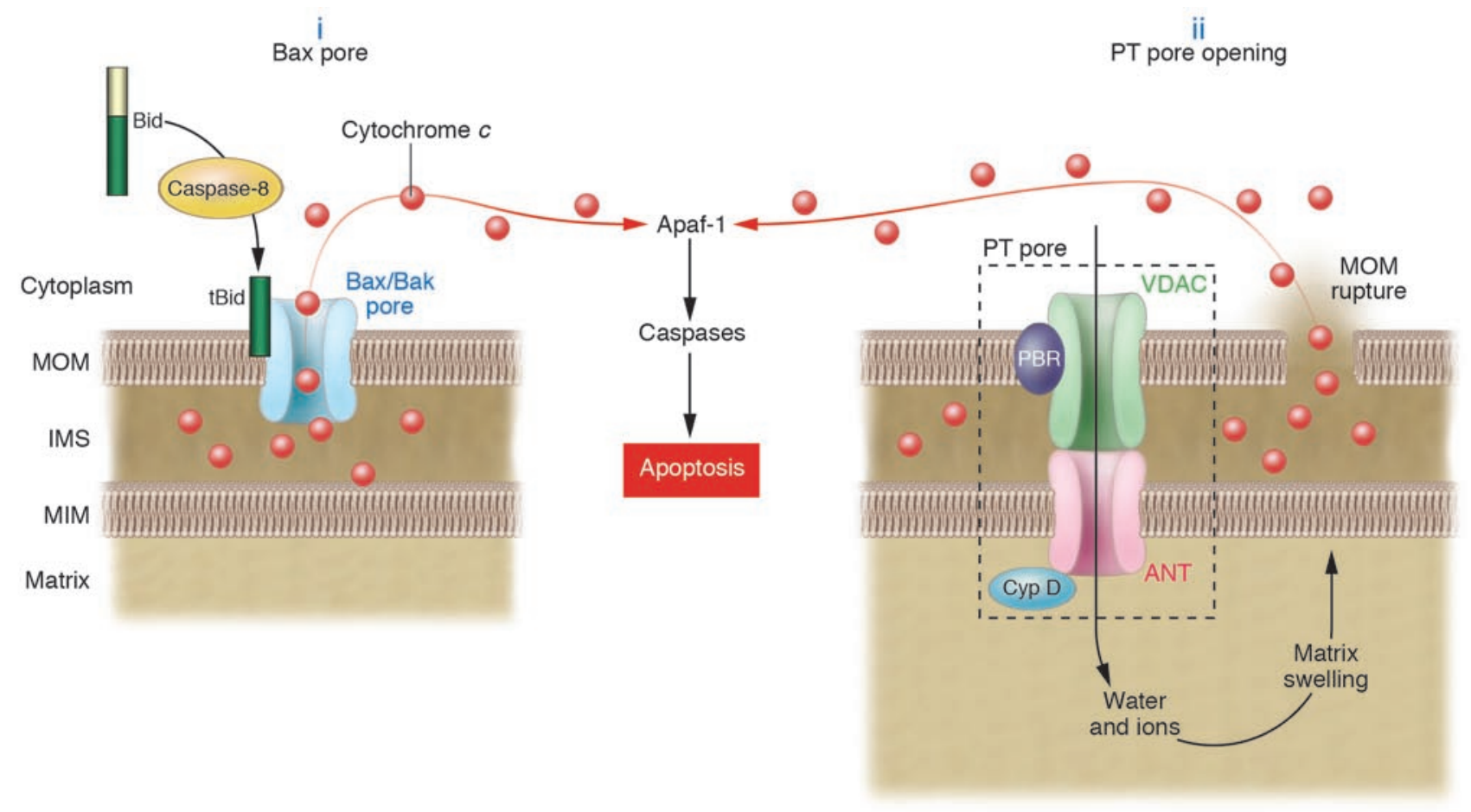

Figure 1

Molecular mechanisms of MOMP. The proposed models of MOMP leading to cytochrome $c$ release are represented. (i) Bax pore. Bax or Bak forms a pore in the MOM after activation by a BH3-only protein such as Bid. (ii) PT pore opening. Opening of the PT pore allows an influx of water and ions into the matrix, causing matrix swelling; this leads to rupture of the MOM, releasing IMS proteins such as cytochrome $c$. MIM, mitochondrial inner membrane; PBR, peripheral benzodiazepine receptor.

membranes and is presumably composed of at least 3 proteins, namely the voltage-dependent anion channel (VDAC) in the outer membrane, the soluble matrix protein cyclophilin D (Cyp D), and the adenine nucleotide translocase (ANT) in the inner membrane (18), although the requirement for ANT is controversial $(25,26)$.

Under normal calcium homeostasis, the PTP exists in a state of low conductance; however, when excess $\mathrm{Ca}^{2+}$ is released from the endoplasmic reticulum and overloads the mitochondria, the pore transitions to a high-conductance state. This passage from low to high conductance is irreversible and strictly depends on the saturation of the calcium-binding sites of the PTP (27). The highconductance conformation allows free diffusion of water and ions between the cytosol and the matrix, causing collapse of $\Delta \Psi_{\mathrm{m}}$ (the inner membrane gradient), uncoupling of oxidative phosphorylation, and swelling of the mitochondrial matrix. This leads to rupture of the MOM and consequent release of IMS proteins.

A few proapoptotic stimuli, such as calcium overload, oxidative stress, or ischemia/reperfusion, seem to mediate cytochrome $c$ release directly through the PT (28). However, the generality of PT as a primary mechanism for MOMP and apoptosis has been questioned, as mitochondrial matrix swelling is not always observed in apoptotic cells $(29,30)$; moreover, mitochondrial depolarization does not always precede the release of cytochrome $c$ and is often blocked by caspase inhibition (31-33). Indeed, in such cases the loss of $\Delta \Psi_{\mathrm{m}}$ does not result from PT, but rather from the caspasedependent cleavage of at least 1 substrate in the respiratory chain: p75, a subunit of complex I (34). Cleavage of p75 disrupts oxygen consumption, increases ROS production, and is 1 of several events that may preclude recovery for the cell (35).
Fortunately, a clear resolution to this controversy over mechanisms of MOMP may be at hand. Two recent papers $(36,37)$ reported use of a genetic approach to determine how important PT is for cell death in vivo (for critical commentaries see refs. 38, 39). These groups produced mice defective in the gene encoding cyclophilin D (Cyp D) and observed that isolated mitochondria from these animals were defective in the PT response, except to extremely high concentrations of $\mathrm{Ca}^{2+}$, consistent with observations that the drug cyclosporin A (CsA) also blocks PT only at lower $\mathrm{Ca}^{2+}$ concentrations. Strikingly, apoptotic cell death in these animals was entirely normal. On the other hand, some forms of cell death, such as those induced by oxygen radicals and $\mathrm{Ca}^{2+}$ overload, were defective. Thus, apoptotic death involving the actions of Bcl-2 family members at mitochondria does not involve Cyp D-dependent PT, whereas other forms of death expected to involve the PT response do depend on Cyp D. Despite the lack of evidence for PT as a mechanism of apoptotic death in general, it remains important to consider therapeutic strategies for inducing PT-mediated cell death selectively in certain cell types, as discussed below.

\section{A unified model for the roles of Bcl-2-family proteins in regulating MOMP}

The Bcl-2 family of proteins (Table 1) includes both proapoptotic and antiapoptotic members, each containing 1 or more Bcl-2 homology domains (BH1 through BH4) (40). Antiapoptotic members such as $\mathrm{Bcl}-2, \mathrm{Bcl}-\mathrm{x}_{\mathrm{L}}$, and $\mathrm{Mcl}-1$ contain all $4 \mathrm{BH}$ domains. The proapoptotic members are divided into 2 subgroups. One of these consists of Bax, Bak, and Bok, which possess domains BH1, BH2, 
Table 1

Subdivisions of Bcl-2-family proteins, based on function and sequence homology

\begin{tabular}{|c|c|c|c|c|}
\hline Category & \multicolumn{2}{|c|}{ Subcategory } & Proteins & Domains \\
\hline \multirow[t]{3}{*}{ Proapoptotic } & Multidomair & & Bax, Bak, Bok & $\mathrm{BH} 1, \mathrm{BH} 2, \mathrm{BH} 3$ \\
\hline & \multirow{2}{*}{ BH3-only } & Direct activator & Bid, Bim & $\mathrm{BH} 3$ \\
\hline & & Derepressor & $\begin{array}{l}\text { Bad, Bik, Bnip3, Puma, } \\
\text { Noxa, Bmf, Hrk, others }\end{array}$ & BH3 \\
\hline
\end{tabular}

or Bid; indeed, synthetic peptides corresponding to the $\mathrm{BH} 3$ domains of these proteins are able to activate $\operatorname{Bax}(20,47)$. The p53 protein can also directly induce Bax-mediated membrane permeabilization in cells and liposomes, although it lacks a clearly identifiable $\mathrm{BH} 3$ domain $(52,53)$. Fourth, the antiapoptotic family members can oppose Bax and Bak as well as the BH3-only proteins (20). Fifth, $\mathrm{BH}$-only proteins fall into 2 functional classes: the direct activators Bim and Bid mentioned above, and the others, which

and $\mathrm{BH} 3$; the other group consists of the more numerous $\mathrm{BH} 3$-only proteins, which include Bid, Bad, Puma, and several others (40).

While several Bcl-2-family proteins possess ion channel activity in lipid bilayers, only the multidomain proapoptotic proteins Bax and Bak can render membranes permeable to cytochrome $c$ or larger macromolecules $(15,20)$. These 2 proteins exhibit a degree of functional redundancy in the mouse, as the ablation of both bax and bak genes results in a much more dramatic apoptotic phenotype than single bax or bak knockouts. Indeed, tissues and cells deficient in both genes are resistant to most stimuli that proceed through mitochondrial and endoplasmic reticulum-dependent pathways (41-44). The 2 proteins do not behave identically, however, since in nonapoptotic cells Bax is mostly free in the cytosol while Bak is constitutively localized in membranes of the mitochondria and endoplasmic reticulum (45).

Regardless of localization, Bax and Bak both seem to be in an inactive state in nonapoptotic cells. An activation process, which is not completely understood, is required for Bax to oligomerize and insert stably into the membrane $(20,46,47)$. The tertiary structure of the antiapoptotic Bcl-2 family member $\mathrm{Bcl}-\mathrm{x}_{\mathrm{L}}$ shows that its helical domains form a hydrophobic groove where the $\mathrm{BH}$-only proteins bind. Bax has a similar structural fold; however, in unactivated, soluble Bax, the $\mathrm{C}$-terminal helix $\alpha 9$ occupies the $\mathrm{BH} 3$ binding groove (48), and helix $\alpha 8$ is also positioned to interfere with potential binding of $\mathrm{BH} 3$ domains (49). Thus, in order to interact with $\mathrm{BH} 3$ domains in other proteins, Bax must undergo a conformational alteration. Indeed, a Bax conformational change is commonly detected through the binding of conformation-sensitive antibodies (50), and the interaction of Bax with membranes is sufficient to enable a conformational change but not membrane insertion or pore formation (51). Bax oligomerization does not occur in solution (20), except in the presence of certain detergents (46), consistent with the idea that interaction with a hydrophobic environment is necessary to destabilize the Bax molecule and allow activation and oligomerization.

In what is commonly known as the "rheostat" model, cell survival is determined by the balance between antiapoptotic Bcl-2family proteins such as $\mathrm{Mcl}-1, \mathrm{Bcl}-\mathrm{x}_{\mathrm{L}}$, or $\mathrm{Bcl}-2$, and proapoptotic $\mathrm{BH} 3$-only proteins. Based on recent findings, we can now consider a more complex "switched rheostat" model (Figure 2) with several additional elements: First, Bax and Bak are the positive effector molecules, based on the biochemical and genetic studies mentioned above. Second, the antiapoptotic relatives act as inhibitors of this permeabilization process, not effectors of an independent survival mechanism, at least with regard to direct effects on MOMP. Third, MOMP mediated by Bax and Bak must be triggered by "direct activator" proteins, such as the $\mathrm{BH} 3$-only proteins Bim

act as "derepressors" by binding competitively to the antiapoptotic family members and thus freeing up the direct activator proteins to induce Bax/Bak-mediated MOMP $(47,54,55)$. Finally, interactions between various $\mathrm{BH}$-only proteins and the antiapoptotic Bcl-2-family proteins exhibit a pattern of overlapping specificities that was previously unappreciated. Recent studies have shown that some of the $\mathrm{BH} 3$-only proteins bind to only a subset of the antiapoptotic proteins, and conversely the antiapoptotic proteins each bind to a subset of the BH3-only proteins $(47,56)$. For example, the BH3-only protein Noxa binds specifically to Mcl-1 and A1. In contrast, Puma, another BH3-only protein, binds to at least 5 different antiapoptotic relatives (56). Moreover, Bak is differentially inhibited by antiapoptotic Bcl-2-family proteins, further illustrating the intricacy of this protein network (57).

Adding to this complexity, a number of proteins unrelated to the Bcl-2 family interact with Bax and either inhibit (58-61) or enhance $(58,62)$ its activation. Bak has been reported to associate with VDAC2 at the mitochondrial membrane, and this inhibits the oligomerization and proapoptotic activity of Bak (63). Although their roles in cell death are not well understood, these

\section{A Rheostat}

BH3-only proteins (Bid, Bim, Puma, etc.)

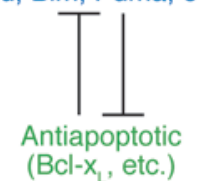

Figure 2

Models of Bcl-2-family function at the mitochondrion during apoptosis. (A) The traditional simple rheostat model assumes that the antiapoptotic $\mathrm{Bcl}-2$-family proteins antagonize the $\mathrm{BH}$-only proteins, in an equal and opposite manner. (B) Recent results suggest a more inclusive and detailed model, which we term the "switched rheostat." Bax and Bak are the effectors of MOMP. Certain BH3-only proteins ("direct activators") and p53 switch on Bax (and possibly Bak) directly and are antagonized by antiapoptotic Bcl-2-family proteins. Other BH3-only proteins ("derepressors") do not activate Bax directly but act by antagonizing the antiapoptotic family members, thereby freeing the direct activators to trigger Bax/Bak-induced MOMP. The dashed lines indicate that the derepressor $\mathrm{BH} 3-$ only proteins have differing specificities for antiapoptotic family members. 
proteins that modulate Bax or Bak activation could be important therapeutic targets (64).

\section{Pathological processes involving MOMP}

As MOMP is a crucial step for many pathways that induce apoptosis, disruption of this event would likely affect cell fate. For example, certain viruses kill the host cell by causing MOMP, while others prevent MOMP to allow propagation of the virus. The HIV protein $\mathrm{Vpr}$ (viral accessory protein $\mathrm{R}$ ) induces MOMP; a mutation in this protein (R77Q) confers resistance to MOMP and is associated with a reduced risk of developing AIDS (65). In contrast, the cytomegalovirus vMIA protein blocks MOMP by forming inactive complexes with $\operatorname{Bax}$ in the $\operatorname{MOM}(66,67)$. Ischemia/reperfusion-mediated injury results from excessive redox stress and mitochondrial uptake of $\mathrm{Ca}^{2+}$, leading to the induction of PT. Some neurodegenerative diseases may involve typical apoptotic pathways and specifically MOMP (68). Manganese has been observed to cause CNS injury resulting in symptoms of Parkinson disease and hepatic encephalopathy leading to chronic liver failure. This involves manganese-induced oxidative stress, leading to MOMP and ultimately apoptosis or necrosis (69).

Mutations in mitochondrial DNA result in a number of metabolic disorders that are mostly due to impairment of oxidative phosphorylation, causing reductions in $\Delta \Psi_{\mathrm{m}}$ and the rate of ATP synthesis (70). Tumorigenesis can be aided by defects in apoptotic pathways enhancing cell survival and transformation, giving cells time to accumulate genetic alterations that deregulate proliferation and differentiation and also favor angiogenesis and cell migration (71). Furthermore, neoplastic cells can evade immune surveillance because their destruction by CTLs and NK cells depends on the integrity of the apoptotic machinery (72). As MOMP plays such a prominent role in these diseases, the components of this pathway are the targets of currently used and potential therapies.

\section{Potential therapies that promote MOMP and cell death}

A goal in treating cancer is to target tumor cells without harming healthy cells. Traditional treatment regimens mainly target rapidly dividing cells, among which tumor cells are the most predominant. However, some normal cell populations have high proliferation rates and are thus vulnerable to such treatments. Compounding this problem, many tumor cells have mutations in key components of the apoptotic machinery, such as p53, allowing them to become resistant to apoptosis. Currently there are a number of drugs in clinical development that are hoped to induce apoptosis only in neoplastic cells by targeting components of the mitochondrial pathway to induce MOMP (Table 2).

It will be advantageous for new therapeutic strategies to bypass the survival adaptations, or take advantage of the distinguishing features, of tumor cells.

Tumor cells in general have higher plasma and mitochondrial membrane potentials compared with normal epithelial cells (73). As a consequence, certain compounds known as cationic lipophilic toxins can preferentially accumulate in the mitochondrial matrix of cancer cells. Malignant cells tend to possess higher numbers of mitochondria, perhaps further enhancing the specificity of these drugs for tumor cells $(73,74)$. MKT-077, a cationic rhodacyanine dye (75), selectively kills malignant cells, in part because of its ability to inhibit mitochondrial respiration, and is the basis of pharmacological studies and phase I clinical trials in chemoresistant solid tumors $(76,77)$.
Photodynamic therapy (PDT) (78) is a therapeutic approach that similarly makes use of the ability of lipophilic cations to target tumor cells preferentially. In PDT, a photosensitizer is irradiated in the presence of molecular oxygen. The resulting ROS production causes cell death. Cationic photosensitizers, such as rhodamine-123, krypto/phthalocyanines, and cationic porphyrins, preferentially accumulate in mitochondria in proportion to $\Delta \Psi_{\text {m }}$; many of these compounds show tumor-destructive activity in vivo. Anionic photosensitizers often have specific affinity for mitochondrial proteins or lipids; for example, verteporfin targets ANT (79). Clinical trials are in progress to evaluate similar drugs for the treatment of several types of tumors (80). Other "mitochondriotoxic" molecules, such as arsenic trioxide (ATO), used to treat acute promyelocytic leukemia (81), work through ROS production. The combination of ATO with ascorbic acid, a substrate of cytochrome $c$ oxidase (82), was successful in treating myeloma cells and phorbol ester-differentiated leukemic cells resistant to classical treatment (83).

The antineoplastic drug lonidamine may induce PT through direct action on ANT (84). This compound was shown to be safe and effective in clinical trials for the treatment of solid tumors (85), as well as in phase II-III trials for the treatment of advanced breast, ovarian, and lung cancer. The combination of lonidamine with diazepam also increased the therapeutic index in the treatment of recurrent glioblastoma multiforme (86). Many other anticancer drugs also directly target components of the PTP. The thiol cross-linker 4-[N-(S-glutathionylacetyl)amino] phenylarsenoxide (GSAO) works similarly to lonidamine, binding to ANT to induce PT. Its killing activity seems to exclusively target proliferating, but not growth-quiescent, endothelial cells in vitro and prevents angiogenesis in solid tumors in mice (87). Betulinic acid (88), a natural pentacyclic triterpenoid, also acts via the PTP (89) and was shown to be effective against neuroectodermal (90) and malignant head and neck tumors (91) among others. Betulinic acid may also cooperate with TRAIL to induce apoptosis in different tumor cell lines and in primary tumor cells, without affecting normal human fibroblasts (92). PK11195 and RO5-4864, 2 ligands for the mitochondrial benzodiazepine receptor, a PTP regulator, are able to resensitize tumor cells to etoposide, doxorubicin, and $\gamma$-irradiation (93-95).

\section{Therapeutic approaches that inhibit MOMP and cell death}

In contrast to cancer, some disease states arise from an excess of apoptosis, and in these cases MOMP is also a potential therapeutic target. The use of antioxidants is an effective method of counteracting the effects of excess ROS production and shows promise for prevention of ischemia/reperfusion injury (96). Manganese superoxide dismutase (MnSOD), a mitochondrial antioxidant enzyme that can inhibit apoptosis, is a survival factor for cancer cells and, when present in small amounts, mediates resistance to inflammatory stimuli and anticancer drugs. MnSOD can be beneficial in reperfusion-induced injury, as it protects mitochondria and thus limits ROS-induced cell death (97).

The Cyp D-deficient mouse was shown to have significant resistance to ischemia/reperfusion-induced cardiac injury, which suggests that Cyp D is a useful drug target for treatment of stroke or myocardial infarction $(36,37)$. Indeed the undecapeptide CsA, which through binding to Cyp D can prevent PTP assembly, has protective properties with respect to ischemic injury. In a model 
Table 2

Summary of the literature concerning various compounds that act on mitochondria and their experimental or clinical stages of development

\begin{tabular}{|c|c|c|c|c|c|}
\hline Drug type & Examples & Target & Cytotoxic activity & Disease indicated & Experimental or clinical use \\
\hline \multirow[t]{3}{*}{$\begin{array}{l}\text { DNA damage } \\
\text { inducers }\end{array}$} & Etoposide & Topoisomerase II & $\begin{array}{l}\text { Cell cycle arrest, } \\
\text { p53 activation (S1, S2) }\end{array}$ & Tumors & $\begin{array}{l}\text { Phase I trials for solid tumors, phase II } \\
\text { trials for ovarian carcinoma, gliomas }\end{array}$ \\
\hline & Cisplatin & $\begin{array}{l}\text { Induces DNA } \\
\text { modifications }\end{array}$ & p53 activation (S3) & $\begin{array}{l}\text { Germ-cell, breast cancer, } \\
\text { head and neck, lung carcinoma }\end{array}$ & $\begin{array}{l}\text { Widely prescribed for a variety } \\
\text { of tumors }\end{array}$ \\
\hline & $\begin{array}{l}\text { Cytosine b-D-arabino- } \\
\text { furanoside (AraC), } \\
\text { 5-fluorouracil (5FU) }\end{array}$ & $\begin{array}{l}\text { Selective inhibitors } \\
\text { of DNA synthesis }\end{array}$ & p53 activation (S4, S5) & $\begin{array}{l}\text { Acute myeloid leukemia, } \\
\text { ovarian cancer (AraC) (S6); breast, } \\
\text { gastrointestinal carcinomas (5FU) }\end{array}$ & $\begin{array}{l}\text { Phase I, II, III clinical trials; } \\
\text { prescribed for certain cancers }\end{array}$ \\
\hline \multirow[t]{2}{*}{$\begin{array}{l}\text { Microtubule } \\
\text { inhibitors }\end{array}$} & Taxol (paclitaxel) & $\begin{array}{l}\beta \text {-Tubulin (stabilizes } \\
\text { microtubules) }\end{array}$ & $\begin{array}{l}\text { Cell cycle arrest, Bim- } \\
\text { dependent apoptosis }\end{array}$ & $\begin{array}{l}\text { Breast, lung, and } \\
\text { ovarian cancer }\end{array}$ & Prescribed \\
\hline & $\begin{array}{l}\text { Vincristine, } \\
\text { vinblastine }\end{array}$ & $\begin{array}{l}\text { Tubulin (destabilizes } \\
\text { microtubules) }\end{array}$ & $\begin{array}{l}\text { Cell cycle arrest, } \\
\text { p53 activation, Bcl-2 } \\
\text { phosphorylation (S7) }\end{array}$ & $\begin{array}{l}\text { Leukemia, lymphoma, } \\
\text { and breast and } \\
\text { lung cancers }\end{array}$ & Prescribed \\
\hline Avicins & & $\begin{array}{l}\text { Ubiquitination/ } \\
\text { Proteasome pathway? } \\
\text { PI3K? }\end{array}$ & $\begin{array}{l}\text { Cell cycle arrest, } \\
\text { MOMP (S8) }\end{array}$ & $\begin{array}{l}\text { Cancer cell lines, chemically } \\
\text { induced mouse skin } \\
\text { carcinogenesis (S9) }\end{array}$ & Preclinical \\
\hline $\begin{array}{l}\mathrm{Bcl}-2 / \mathrm{Bcl}-\mathrm{x} \\
\text { inhibitors }\end{array}$ & $\begin{array}{l}\text { HA14-1, antimycin A, } \\
\text { BH3ls, YC-137 }\end{array}$ & $\begin{array}{l}\text { BCl-2 or } \\
\text { BCl- } \mathrm{X}_{\mathrm{L}}\end{array}$ & $\begin{array}{l}\text { Bcl-2 or Bcl- } \mathrm{x}_{\mathrm{L}} \\
\text { inhibition, MOMP } \\
\text { (S10-S13) }\end{array}$ & $\begin{array}{l}\text { Antitumor against Bcl-2- } \\
\text { overexpressing cells } \\
\text { (S10, S11) }\end{array}$ & $\begin{array}{l}\text { Cell lines overexpressing Bcl-2 (HA14-1) } \\
\text { (S10) or Bcl-2/Bcl- } \mathrm{x}_{\mathrm{L}}(\mathrm{antimycin} \mathrm{A})(\mathrm{S} 11) \text {; } \\
\text { in vitro and in vivo (BH3ls) (S12); } \\
\text { in vitro and in cancer cells lines } \\
\text { overexpressing Bcl-2 (YC-137) (S13) }\end{array}$ \\
\hline $\begin{array}{l}\text { BH3-only } \\
\text { mimetics }\end{array}$ & $\begin{array}{l}\text { Stapled Bid BH3 } \\
\text { peptide, lactam-bridged } \\
\text { BH3s (S14), Bax BH3 } \\
\text { (S15) }\end{array}$ & $\begin{array}{l}\text { Bax/Bak or } \\
\text { Bax/Bcl-2 }\end{array}$ & $\begin{array}{l}\text { Bax or Bak activation, } \\
\text { induction of MOMP (S16) }\end{array}$ & $\begin{array}{l}\text { Antitumor in cell culture and } \\
\text { in mouse leukemic } \\
\text { model (SAHB BH3) (S16) }\end{array}$ & Mouse model (SAHB BH3) (S16) \\
\hline $\begin{array}{l}\text { Delocalized } \\
\text { lipophilic } \\
\text { cations (DLCS) }\end{array}$ & $\begin{array}{l}\text { MKT-077, } \\
\text { dequalinium (DEQ-B) } \\
\text { (S17), F16 }\end{array}$ & $\begin{array}{l}\text { Mitochondrial } \\
\text { matrix }\left(\Delta \Psi_{\mathrm{m}}\right)\end{array}$ & $\begin{array}{l}\text { Cell cycle arrest, } \\
\text { inhibition of respiration, } \\
\text { MOMP (S18-S20) }\end{array}$ & $\begin{array}{l}\text { Breast, ovary, endometrial, } \\
\text { colon, non-small cell } \\
\text { lung carcinoma }\end{array}$ & $\begin{array}{l}\text { Phase I trials for chemoresistant) } \\
\text { solid tumors (MKT-077) (S21, S22); } \\
\text { in vitro (F16) (S19) }\end{array}$ \\
\hline $\begin{array}{l}\text { Lipophilic } \\
\text { agents }\end{array}$ & Hyperforin & Mitochondria & $\begin{array}{l}\text { Loss of } \Delta \Psi_{\mathrm{m}} \\
\operatorname{MOMP}(\mathrm{S} 23)\end{array}$ & $\begin{array}{l}\text { Inhibit tumor growth, cancer } \\
\text { invasion, and metastasis (S24) }\end{array}$ & $\begin{array}{l}\text { Prevent cancer spread and metastatic } \\
\text { growth in mice and rats (S23, S24) }\end{array}$ \\
\hline $\begin{array}{l}\text { Cationic } \\
\text { photosensitizers }\end{array}$ & $\begin{array}{l}\text { Rhodamine } 123, \text { krypto/ } \\
\text { phthalocyanines, } \\
\text { cationic porphyrins }\end{array}$ & $\begin{array}{l}\text { Mitochondrial } \\
\text { matrix }\left(\Delta \Psi_{\mathrm{m}}\right)\end{array}$ & $\begin{array}{l}\text { Mitochondrial photodamage, } \\
\text { respiratory chain enzyme } \\
\text { inhibition, MOMP (S25) }\end{array}$ & $\begin{array}{l}\text { Rat and mouse cancer } \\
\text { cell lines (S25) }\end{array}$ & Preclinical \\
\hline $\begin{array}{l}\text { Hydroxy- } \\
\text { chalcones }\end{array}$ & $\begin{array}{l}\text { Phloretin, isoliquiritigen, } \\
\text { butein }\end{array}$ & Mitochondria & $\begin{array}{l}\text { Mitochondrial uncoupling, } \\
\Delta \Psi_{\mathrm{m}} \text { loss, increased oxygen } \\
\text { uptake (S26) }\end{array}$ & $\begin{array}{l}\text { K562 leukemia, breast cancer, } \\
\text { and melanoma cells (S26) }\end{array}$ & Preclinical \\
\hline \multirow[t]{2}{*}{$\begin{array}{l}\text { Cytotoxic } \\
\text { peptides }\end{array}$} & $(\mathrm{KLAKLAK})_{2}$ & $\begin{array}{l}\text { Mitochondrial } \\
\text { matrix }\end{array}$ & $\begin{array}{l}\text { Loss of membrane barrier } \\
\text { function, mitochondrial } \\
\text { swelling }\end{array}$ & $\begin{array}{l}\text { Antitumor activity in mice, } \\
\text { selective toxicity for angiogenic } \\
\text { endothelial cells (S27) }\end{array}$ & In mice \\
\hline & GSAO & ANT & $\begin{array}{l}\mathrm{Ca}^{2+-d e p e n d e n t ~ P T,} \\
\text { ATP depletion, MOMP (S28) }\end{array}$ & $\begin{array}{l}\text { Inhibits tumor growth } \\
\text { in mice (S28) }\end{array}$ & In mice \\
\hline \multirow[t]{3}{*}{$\begin{array}{l}\text { Respiratory chain } \\
\text { inhibitors }\end{array}$} & $\begin{array}{l}\text { Benzopyran-based } \\
\text { inhibitors, arsenic trioxide } \\
\text { (ATO; see below) }\end{array}$ & Complex I (S29) & Not described & Cancer & $\begin{array}{l}\text { Potential chemotherapeutic/ } \\
\text { chemopreventive candidates (S29) }\end{array}$ \\
\hline & Polyketide inhibitors & $F(0)-F(1)$-ATPase $(S 30)$ & Not described & Cancer cell lines (S30) & Human cancer cell lines (S30) \\
\hline & Tamoxifen & Complex III/IV (S31) & $\begin{array}{l}\text { Mitochondrial uncoupling, } \\
\text { MOMP }\end{array}$ & Breast cancer & Prescribed \\
\hline $\begin{array}{l}\text { Anionic photo- } \\
\text { sensitizers }\end{array}$ & Verteporfin & ANT (S32) & $\begin{array}{l}\text { ROS generation, PT, } \\
\text { and MOMP (S32) }\end{array}$ & $\begin{array}{l}\text { Age-related } \\
\text { macular degeneration }\end{array}$ & Prescribed \\
\hline \multirow[t]{3}{*}{$\begin{array}{l}\text { ROS } \\
\text { generators }\end{array}$} & $\begin{array}{l}\text { CD437, short-chain } \\
\text { fatty acids } \\
\text { (propionate, acetate) }\end{array}$ & ANT $(\mathrm{S} 33, \mathrm{~S} 34)$ & $\begin{array}{l}\text { ROS generation, } \\
\text { PT, and MOMP } \\
\text { (S34-S36) }\end{array}$ & $\begin{array}{l}\text { Solid tumors, cutaneous carcinomas } \\
\text { and leukemias (CD437) (S33, S35, } \\
\text { S36), colorectal carcinoma cells } \\
\text { (short-chain fatty acids) (S34) }\end{array}$ & $\begin{array}{l}\text { In vitro and in malignant cell lines } \\
\text { (CD437) (S33, S35, S36); both in vitro } \\
\text { and in human colorectal carcinoma } \\
\text { cell lines (S34) }\end{array}$ \\
\hline & ATO & ANT (S33) & $\begin{array}{l}\text { ROS generation, PT, and } \\
\text { MOMP (S33, S37) }\end{array}$ & $\begin{array}{l}\text { Acute promyelocytic } \\
\text { leukemia }(\mathrm{S} 38, \mathrm{~S} 39)\end{array}$ & $\begin{array}{l}\text { Phase I/II trials of dual therapy ATO/ascorbic } \\
\text { acid for chemoresistant myeloma cells, } \\
\text { phorbol ester-differentiated leukemic cells } \\
\text { (S40) }\end{array}$ \\
\hline & Bortezomib (Velcade) & Proteasomes & $\begin{array}{l}\text { ROS generation, PT, } \\
\text { and MOMP (S41) }\end{array}$ & $\begin{array}{l}\text { Multiple myeloma and chronic } \\
\text { lymphocytic leukemia }\end{array}$ & $\begin{array}{l}\text { Phase } 1 / I I \text { trials for multiple myeloma } \\
\text { and some solid tumors (S42) }\end{array}$ \\
\hline $\begin{array}{l}\text { Benzodiazepine } \\
\text { ligands }\end{array}$ & $\begin{array}{l}\text { PK11195, } \\
\text { R05-4864 }\end{array}$ & $\begin{array}{l}\text { Mitochondrial } \\
\text { benzodiazepine receptor }\end{array}$ & PT and MOMP (S43) & $\begin{array}{l}\text { Increases cytotoxicity of doxorubicin } \\
\text { etoposide, ionizing radiation in } \\
\text { human cancer cell lines (S43-S45) }\end{array}$ & $\begin{array}{l}\text { Assays in human tumor cell lines } \\
\text { and in mice (S43-S45) }\end{array}$ \\
\hline \multirow[t]{4}{*}{$\begin{array}{l}\text { Other drugs } \\
\text { that target the PTP }\end{array}$} & MT-21 & ANT (S46) & $\begin{array}{l}\text { PT and MOMP } \\
\text { (S46, S47) }\end{array}$ & Human leukemia HL-60 cells & $\begin{array}{l}\text { In vitro and in cancer cell lines } \\
(\mathrm{S} 46, \mathrm{~S} 47)\end{array}$ \\
\hline & Betulinic acid & PTP & PT and MOMP & $\begin{array}{l}\text { Malignant brain tumor cells, } \\
\text { neuroectodermal tumors and } \\
\text { melanoma (S48-S52) }\end{array}$ & $\begin{array}{l}\text { In tumor cell lines and in mice } \\
\text { (S48-S52) }\end{array}$ \\
\hline & Lonidamine & ANT (S33) & PT and MOMP (S33) & Tumors (S53) & $\begin{array}{l}\text { Trials in combination with standard } \\
\text { chemotherapy for solid tumors, phase II/III } \\
\text { trials for advanced breast, ovarian, and } \\
\text { lung cancers (S40, S54, S55) }\end{array}$ \\
\hline & CsA & Cyp D & Prevention of PT and MOMP & Ischemia/reperfusion (S56, S57) & $\begin{array}{l}\text { Used as an immunosuppressant for } \\
\text { transplants (S58); neuroprotection in rats }\end{array}$ \\
\hline \multirow[t]{3}{*}{ Antioxidants } & MnSOD & Mitochondria & Prevention of MOMP (S59) & Ischemia/reperfusion (S59) & In transgenic mice (S59) \\
\hline & $\mathrm{MCl}-186$ & Mitochondria & Inhibition of PT and MOMP (S60) & Reperfusion injury in rats (S61) & In rats $(S 60, S 61)$ \\
\hline & $\begin{array}{l}\text { MitoVitE, MitoQ } \\
\text { (targeted to mitochondria } \\
\text { with the TPP lipophilic cation) }\end{array}$ & Mitochondria $\left(\Delta \Psi_{\mathrm{m}}\right)$ & $\begin{array}{l}\text { MOMP inhibition; prevention } \\
\text { of lipid peroxidation, oxidative } \\
\text { stress, and damage (S62-S64) }\end{array}$ & $\begin{array}{l}\text { Prevents mitochondrial damage } \\
\text { induced by } \mathrm{H}_{2} \mathrm{O}_{2}(\mathrm{~S} 64)\end{array}$ & In human cell lines (S64) \\
\hline
\end{tabular}

"In vitro" refers to biochemical (cell-free) studies. References S1-S64 are available online with this article; doi:10.1172/JCI26274DS1. 
of transient focal cerebral ischemia, CsA is neuroprotective when administered before or immediately after ischemia, resulting in a smaller infarct $(98,99)$. CsA is widely used as an immunosuppressant to prevent organ rejection following transplantation. This immunosuppressant function of CsA is due not to its effects on Cyp D, but rather to its ability to inhibit the calcineurin-mediated upregulation of a number of inflammatory cytokines. NIM811, an analog of CsA, retains the neuroprotective but not the immunosuppressive function, suggesting that the ability of CsA to protect cells from ischemic injury results from the neutralization of Cyp D and hence PT (100). Although CsA has protective effects in ischemia/reperfusion models, this drug also caused neurotoxicity in up to $60 \%$ of transplants (101). Indeed, studies have shown that CsA can be both neurotoxic to normal cells and neuroprotective, in similar dose ranges, to cells that have received an ischemic injury (102). Thus, although CsA is a prototype drug for the prevention or treatment of ischemia/reperfusion injury, its functions and effects are still not fully understood.

The ability of viruses to induce apoptosis also provides potential targets for drugs that can be used in the treatment of certain viral infections. The HIV-encoded protein Vpr, for example, induces apoptosis by causing MOMP and is thought to do so through interaction with ANT, as Vpr fails to kill ANT-deficient cells (103). HIV protease inhibitors can inhibit Vpr-induced PT and MOMP, and inhibitors of $\mathrm{Vpr}$ or the $\mathrm{Vpr} / \mathrm{ANT}$ interaction may have benefits in the clinic (104).

\section{Bcl-2 inhibitors}

Often, tumors overexpress $\mathrm{Bcl}-2$ or related antiapoptotic proteins and as a result are resistant to apoptosis induced by many chemotherapeutic agents. Therefore, there is interest in developing small molecules and peptides that mimic proapoptotic $\mathrm{BH} 3$-only proteins to overcome $\mathrm{Bcl}-2$-associated resistance. The nonpeptidic compound HA14-1 was identified using a computer screening approach exploiting the 3D structure of Bcl-2 (105). HA14-1 can bind to the BH3-binding site of Bcl-2, thus mimicking a BH3-only protein, and can induce apoptosis in tumor cells. Chemical screens for molecules that can inhibit the antiapoptotic activity of $\mathrm{Bcl}-2$ and $\mathrm{Bcl}-\mathrm{x}_{\mathrm{L}}$ have identified antimycin A (coincidentally, already known as an inhibitor of respiratory complex III) and inhibitors known as BH3Is $(106,107)$. Antimycin A, like HA14-1 and the BH3Is, binds the BH3-binding pocket to induce apoptosis in cells that overexpress $\mathrm{Bcl}-2$ or $\mathrm{Bcl}-\mathrm{x}_{\mathrm{L}}$. While these compounds serve as a proof of principle for this approach, compounds with improved affinities for $\mathrm{Bcl}-2$ and $\mathrm{Bcl}-\mathrm{x}_{\mathrm{L}}$ must be identified if they are to be considered for use in a clinical setting. Indeed, very recently, ABT-737, a novel inhibitor of Bcl-2, $\mathrm{Bcl}-\mathrm{x}_{\mathrm{L}}$, and $\mathrm{Bcl}-\mathrm{w}$, was reported to bind to these molecules with an affinity orders of magnitude higher than that of previously described Bcl-2 antagonist compounds (108). ABT-737 can sensitize cells to killing by other apoptosis-inducing stimuli but also showed significant efficacy as a single agent against lymphoma and small-cell lung carcinoma cell lines and primary cells derived from patients, and in animal models. The inability of ABT-737 to antagonize Mcl-1 (another antiapoptotic relative of Bcl-2) will likely limit the effectiveness of this compound against tumors in which Mcl-1 is elevated or stabilized.

Synthetic BH3 peptides can also function as antagonists of $\mathrm{Bcl}-\mathrm{x}_{\mathrm{L}}$, sensitizing cells to proapoptotic stimuli such as anti-Fas treatment (109). However, peptides tend to be degraded and lose their secondary structure easily, severely limiting their efficacy. Korsmeyer and colleagues recently described a method of overcoming these problems called hydrocarbon stapling (110). A stapled Bid BH3 peptide was found to be both cell permeable and more stable than the unmodified peptide and showed efficacy in a mouse leukemic model.

The Nur77 protein induces apoptosis by binding to $\mathrm{Bcl}-2$. Nur77 binds not to the BH3-binding pocket but rather to the loop region between the $\mathrm{BH} 4$ and $\mathrm{BH} 3$ domains (111). Deletion of this loop blocks paclitaxel-induced death, and thus the loop may be required for certain anticancer drugs to be effective (112). Also, deamidation of residues in this loop in $\mathrm{Bcl}-\mathrm{x}_{\mathrm{L}}$ reduces its protective activity (113). Therefore, drugs that target this region may be effective inhibitors of $\mathrm{Bcl}-2$. The use of antisense $\mathrm{Bcl}-2$ oligonucleotides is another potential method of inhibiting Bcl-2 in treatment of cancer. However, studies have shown that when used alone to treat lymphoma, antisense Bcl-2 has dose-limiting toxicities (114). But when used in combination with existing chemotherapeutic drugs (e.g., mitoxantrone in the treatment of prostate cancer [ref. 115]), lower doses may be effective, thus reducing toxic side effects.

A question arises, however: How can compounds targeting Bcl-2 and related proteins selectively kill cancer cells? The unified model shown in Figure 2 reflects a greater flexibility for cell type-specific regulation of apoptosis by the Bcl-2 family than previously assumed. As a corollary, we can envision therapeutic applications in which a certain cell type is targeted selectively based on the subsets of BH3-only proteins and antiapoptotic $\mathrm{Bcl}-2$ relatives it expresses. In particular, the model in Figure 2 predicts that cells lacking expression of direct activator BH3-only proteins should not undergo apoptosis when the antiapoptotic proteins are downregulated. In contrast, tumor cells, which may be under constant oncogenic stress, may constitutively express a direct Bax/Bak activator protein such as $\operatorname{Bim}$ (116), which then is presumably held in check by antiapoptotic proteins such as Bcl-2 (117). If this turns out to be true generally, the introduction of a cell-permeable derepressor-type peptide or a small-compound inhibitor of antiapoptotic $\mathrm{Bcl}-2$-family proteins might induce apoptosis selectively in a variety of tumors (108).

\section{Conclusion}

Mitochondria hold great promise as targets for therapeutic intervention. However, only a fraction of this potential has so far been realized. Ironically, it may turn out that some therapies succeed by unintentionally affecting MOMP, despite being directed at other biochemical targets. Indeed, a recent study showed that a promising proteasome inhibitor, bortezomib, restored paclitaxel sensitivity to Ras-transformed cells by protecting the $\mathrm{BH} 3$-only protein, Bim, from proteasomal degradation (118). Although we are certainly glad for such serendipity, there is hope that, in time, a variety of mitochondria-directed therapies, such as more potent inhibitors of Bcl-2 and related proteins (108), will be put into common use.

Address correspondence to: Donald D. Newmeyer, La Jolla Institute for Allergy and Immunology, Department of Cellular Immunology, 10355 Science Center Drive, San Diego, California 92121, USA. Phone: (858) 558-3539; Fax: (858) 558-3526; E-mail: don@liai.org.

Lisa Bouchier-Hayes and Lydia Lartigue contributed equally to this work. 
1. Weissig, V., Boddapati, S.V., D’Souza, G.G.M., and Cheng, S.M. 2004. Targeting of low-molecular weight drugs to mammalian mitochondria. Drug Design Reviews - Online. 1:15-28.

2. Martin, S.J., and Green, D.R. 1995. Protease activation during apoptosis: death by a thousand cuts? Cell. 82:349-352.

3. Newmeyer, D.D., and Ferguson-Miller, S. 2003. Mitochondria: releasing power for life and unleashing the machineries of death. Cell. 112:481-490.

4. Adrain, C., and Martin, S.J. 2001. The mitochondrial apoptosome: a killer unleashed by the cytochrome seas. Trends Biochem. Sci. 26:390-397.

5. Du, C., Fang, M., Li, Y., Li, L., and Wang, X. 2000. Smac, a mitochondrial protein that promotes cytochrome c-dependent caspase activation by eliminating IAP inhibition. Cell. 102:33-42.

6. Suzuki, Y., et al. 2001. A serine protease, HtrA2, is released from the mitochondria and interacts with XIAP, inducing cell death. Mol. Cell. 8:613-621.

7. Klein, J.A., et al. 2002. The harlequin mouse mutation downregulates apoptosis-inducing factor. Nature. 419:367-374.

8. Jones, J.M., et al. 2003. Loss of Omi mitochondrial protease activity causes the neuromuscular disorder of mnd2 mutant mice. Nature. 425:721-727.

9. Uren, R.T., et al. 2005. Mitochondrial release of pro-apoptotic proteins: electrostatic interac tions can hold cytochrome $\mathrm{c}$ but not Smac/DIABLO to mitochondrial membranes. J. Biol. Chem. 280:2266-2274.

10. Otera, H., Ohsakaya, S., Nagaura, Z.I., Ishihara, N., and Mihara, K. 2005. Export of mitochondrial AIF in response to proapoptotic stimuli depends on processing at the intermembrane space. $E M B O J$. 24:1375-1386

11. Polster, B.M., Basanez, G., Etxebarria, A., Hardwick, J.M., and Nicholls, D.G. 2005. Calpain I induces cleavage and release of apoptosis-inducing factor from isolated mitochondria. J. Biol. Chem. 280:6447-6454.

12. Von Ahsen, O., Waterhouse, N.J., Kuwana, T., Newmeyer, D.D., and Green, D.R. 2000. The 'harmless' release of cytochrome c. Cell Death Differ. 7:1192-1199.

13. Kuwana, T., and Newmeyer, D.D. 2003. Bcl-2-family proteins and the role of mitochondria in apoptosis. Curr. Opin. Cell Biol. 15:691-699.

14. Tsujimoto, Y., and Shimizu, S. 2000. VDAC regulation by the Bcl-2 family of proteins. Cell Death Differ. 7:1174-1181.

15. Korsmeyer, S.J., et al. 2000. Pro-apoptotic cascade activates BID, which oligomerizes BAK or BAX into pores that result in the release of cytochrome $c$. Cell Death Differ. 7:1166-1173.

16. Harris, M.H., and Thompson, C.B. 2000. The role of the Bcl-2 family in the regulation of outer mitochondrial membrane permeability. Cell Death Differ 7:1182-1191

17. Martinou, J.C., and Green, D.R. 2001. Breaking the mitochondrial barrier. Nat. Rev. Mol. Cell Biol. 2:63-67.

18. Zamzami, N., and Kroemer, G. 2001. The mitochondrion in apoptosis: how Pandora's box opens [review]. Nat. Rev. Mol. Cell Biol. 2:67-71.

19. Martinou, J.C., Desagher, S., and Antonsson, B. 2000. Cytochrome c release from mitochondria: all or nothing. Nat. Cell Biol. 2:E41-E43.

20. Kuwana, T., et al. 2002. Bid, Bax, and lipids cooperate to form supramolecular openings in the outer mitochondrial membrane. Cell. 111:331-342.

21. Scorrano, L., et al. 2002. A distinct pathway remodels mitochondrial cristae and mobilizes cytochrome c during apoptosis. Dev. Cell. 2:55-67.

22. Bossy-Wetzel, E., Barsoum, M.J., Godzik, A., Schwarzenbacher, R., and Lipton, S.A. 2003. Mitochondrial fission in apoptosis, neurodegeneration and aging. Curr. Opin. Cell Biol. 15:706-716.
23. Scorrano, L. 2003. Divide et impera: Ca2+ signals, mitochondrial fission and sensitization to apoptosis. Cell Death Differ. 10:1287-1289.

24. Lee, Y., Jeong, S.-Y., Karbowski, M., Smith, C.L., and Youle, R.J. 2004. Roles of the mammalian mitochondrial fission and fusion mediators Fis1, Drp1, and Opa1 in apoptosis. Mol. Biol. Cell. 15:5001-5011.

25. Kokoszka, J.E., et al. 2004. The ADP/ATP translocator is not essential for the mitochondrial permeability transition pore. Nature. 427:461-465.

26. Halestrap, A.P. 2004. Mitochondrial permeability: dual role for the ADP/ATP translocator? Nature. 430:1 page following 983

27. Ichas, F., and Mazat, J.P. 1998. From calcium signaling to cell death: two conformations for the mitochondrial permeability transition pore. Switching from low- to high-conductance state. Biochim. Biophys. Acta. 1366:33-50.

28. Crompton, M. 1999. The mitochondrial permeability transition pore and its role in cell death. Biochem. J. 341:233-249.

29. Jurgensmeier, J.M., et al. 1998. Bax directly induces release of cytochrome $\mathrm{c}$ from isolated mitochondria. Proc. Natl. Acad. Sci. U. S. A. 95:4997-5002.

30. De Giorgi, F., et al. 2002. The permeability transition pore signals apoptosis by directing Bax translocation and multimerization. FASEBJ. 16:607-609.

31. Bossy-Wetzel, E., Newmeyer, D.D., and Green, D.R. 1998. Mitochondrial cytochrome c release in apoptosis occurs upstream of DEVD-specific caspase activation and independently of mitochondrial transmembrane depolarization. EMBOJ. 17:37-49.

32. von Ahsen, O., et al. 2000. Preservation of mitochondrial structure and function after Bid- or Bax-mediated cytochrome c release. J. Cell Biol. 150:1027-1036.

33. Waterhouse, N.J., et al. 2001. Cytochrome c maintains mitochondrial transmembrane potential and ATP generation after outer mitochondrial membrane permeabilization during the apoptotic process. J. Cell Biol. 153:319-328.

34. Ricci, J.E., et al. 2004. Disruption of mitochondrial function during apoptosis is mediated by caspase cleavage of the p75 subunit of complex I of the electron transport chain. Cell. 117:773-786.

35. Ricci, J.E., Gottlieb, R.A., and Green, D.R. 2003. Caspase-mediated loss of mitochondrial function and generation of reactive oxygen species during apoptosis. J. Cell Biol. 160:65-75

36. Baines, C.P., et al. 2005. Loss of cyclophilin D reveals a critical role for mitochondrial permeability transition in cell death. Nature. 434:658-662.

37. Nakagawa, T., et al. 2005. Cyclophilin D-dependent mitochondrial permeability transition regulates some necrotic but not apoptotic cell death. Nature. 434:652-658

38. Green, D.R. 2005. Apoptotic pathways: ten minutes to dead. Cell. 121:671-674.

39. Halestrap, A. 2005. Biochemistry: a pore way to die. Nature. 434:578-579.

40. Adams, J.M., and Cory, S. 1998. The Bcl-2 protein family: arbiters of cell survival. Science. 281:1322-1326.

41. Scorrano, L., et al. 2003. BAX and BAK regulation of endoplasmic reticulum Ca2+: a control point for apoptosis. Science. 300:135-139.

42. Wei, M.C., et al. 2001. Proapoptotic BAX and BAK: a requisite gateway to mitochondrial dysfunction and death. Science. 292:727-730

43. Lindsten, T., et al. 2000. The combined functions of proapoptotic Bcl-2 family members bak and bax are essential for normal development of multiple tissues. Mol. Cell. 6:1389-1399.

44. Knudson, C.M., Tung, K.S., Tourtellotte, W.G., Brown, G.A., and Korsmeyer, S.J. 1995. Bax-deficient mice with lymphoid hyperplasia and male germ cell death. Science. 270:96-99.

45. Nechushtan, A., Smith, C.L., Lamensdorf, I., Yoon, S.H., and Youle, R.J. 2001. Bax and Bak coalesce into novel mitochondria-associated clusters during apoptosis. J. Cell Biol. 153:1265-1276.

46. Eskes, R., Desagher, S., Antonsson, B., and Martinou, J.C. 2000. Bid induces the oligomerization and insertion of Bax into the outer mitochondrial membrane. Mol. Cell. Biol. 20:929-935.

47. Kuwana, T., et al. 2005. BH3 domains of BH3only proteins differentially regulate Bax-mediated mitochondrial membrane permeabilization both directly and indirectly. Mol. Cell. 17:525-535.

48. Suzuki, M., Youle, R.J., and Tjandra, N. 2000. Structure of Bax: coregulation of dimer formation and intracellular localization. Cell. 103:645-654.

49. Liu, X., Dai, S., Zhu, Y., Marrack, P., and Kappler, J.W. 2003. The structure of a Bcl-xL/Bim fragment complex: implications for Bim function. Immunity. 19:341-352.

50. Desagher, S., et al. 1999. Bid-induced conformational change of Bax is responsible for mitochondrial cytochrome $\mathrm{c}$ release during apoptosis. J. Cell Biol. 144:891-901.

51. Yethon, J.A., Epand, R.F., Leber, B., Epand, R.M., and Andrews, D.W. 2003. Interaction with a membrane surface triggers a reversible conformational change in Bax normally associated with induction of apoptosis. J. Biol. Chem. 278:48935-48941.

52. Chipuk, J.E., Maurer, U., Green, D.R., and Schuler, M. 2003. Pharmacologic activation of p53 elicits Bax-dependent apoptosis in the absence of transcription. Cancer Cell. 4:371-381.

53. Chipuk, J.E., et al. 2004. Direct activation of Bax by p53 mediates mitochondrial membrane permeabilization and apoptosis. Science. 303:1010-1014.

54. Letai, A., et al. 2002. Distinct BH3 domains either sensitize or activate mitochondrial apoptosis, serving as prototype cancer therapeutics. Cancer Cell. 2:183-192.

55. Cartron, P.F., et al. 2004. The first alpha helix of Bax plays a necessary role in its ligand-induced activation by the $\mathrm{BH} 3$-only proteins Bid and PUMA. Mol. Cell. 16:807-818.

56. Chen, L., et al. 2005. Differential targeting of prosurvival $\mathrm{Bcl}-2$ proteins by their $\mathrm{BH} 3$-only ligands allows complementary apoptotic function. Mol. Cell. 17:393-403.

57. Willis, S.N., et al. 2005. Proapoptotic Bak is sequestered by $\mathrm{Mcl}-1$ and $\mathrm{Bcl}-\mathrm{x}_{\mathrm{L}}$, but not $\mathrm{Bcl}-2$, until displaced by $\mathrm{BH} 3$-only proteins. Genes Dev. 19:1294-1305.

58. Tan, K.O., et al. 2001. MAP-1, a novel proapoptotic protein containing a $\mathrm{BH} 3$-like motif that associates with Bax through its Bcl-2 homology domains. J. Biol. Chem. 276:2802-2807.

59. Sawada, M., et al. 2003. Ku70 suppresses the apoptotic translocation of Bax to mitochondria. Nat. Cell Biol. 5:320-329.

60. Guo, B., et al. 2003. Humanin peptide suppresses apoptosis by interfering with Bax activation. Nature. 423:456-461.

61. Cohen, H.Y., et al. 2004. Acetylation of the C terminus of Ku70 by CBP and PCAF controls Bax-mediated apoptosis. Mol. Cell. 13:627-638.

62. Cuddeback, S.M., et al. 2001. Molecular cloning and characterization of Bif-1. A novel Src homology 3 domain-containing protein that associates with Bax. J. Biol. Chem. 276:20559-20565.

63. Cheng, E.H., Sheiko, T.V., Fisher, J.K., Craigen, W.J., and Korsmeyer, S.J. 2003. VDAC2 inhibits BAK activation and mitochondrial apoptosis. Science. 301:513-517.

64. Sawada, M., Hayes, P., and Matsuyama, S. 2003. Cytoprotective membrane-permeable peptides designed from the Bax-binding domain of $\mathrm{Ku} 70$. Nat. Cell Biol. 5:352-357.

65. Lum, J.J., et al. 2003. Vpr R77Q is associated with long-term nonprogressive HIV infection and impaired induction of apoptosis. J. Clin. Invest. 111:1547-1554. doi:10.1172/JCI200316233. 
66. Poncet, D., et al. 2004. An anti-apoptotic viral protein that recruits Bax to mitochondria. J. Biol. Chem. 279:22605-22614.

67. Arnoult, D., et al. 2004. Cytomegalovirus cell death suppressor vMIA blocks Bax- but not Bakmediated apoptosis by binding and sequestering Bax at mitochondria. Proc. Natl. Acad. Sci. U. S. A. 101:7988-7993.

68. Lindholm, D., Eriksson, O., and Korhonen, L. 2004. Mitochondrial proteins in neuronal degeneration. Biochem. Biophys. Res. Commun. 321:753-758.

69. Rao, K.V., and Norenberg, M.D. 2004. Manganese induces the mitochondrial permeability transition in cultured astrocytes. J. Biol. Chem. 279:32333-32338.

70. Lowell, B.B., and Shulman, G.I. 2005. Mitochondrial dysfunction and type 2 diabetes. Science. 307:384-387.

71. Reed, J.C. 1999. Dysregulation of apoptosis in cancer. J. Clin. Oncol. 17:2941-2953.

72. Tschopp, J., Martinon, F., and Hofmann, K. 1999. Apoptosis: silencing the death receptors [review]. Curr. Biol. 9:R381-R384.

73. Davis, S., Weiss, M.J., Wong, J.R., Lampidis, T.J., and Chen, L.B. 1985. Mitochondrial and plasma membrane potentials cause unusual accumulation and retention of rhodamine 123 by human breast adenocarcinoma-derived MCF-7 cells. J. Biol. Chem. 260:13844-13850.

74. Leprat, P., Ratinaud, M.H., and Julien, R. 1990. A new method for testing cell ageing using two mitochondria specific fluorescent probes. Mech. Ageing Dev. 52:149-167.

75. Modica-Napolitano, J.S., et al. 1996. Selective damage to carcinoma mitochondria by the rhodacyanine MKT-077. Cancer Res. 56:544-550.

76. Propper, D.J., et al. 1999. Phase I trial of the selective mitochondrial toxin MKT077 in chemo-resistant solid tumours. Ann. Oncol. 10:923-927.

77. Britten, C.D., et al. 2000. A phase I and pharmacokinetic study of the mitochondrial-specific rhodacyanine dye analog MKT 077. Clin. Cancer Res. 6:42-49.

78. Morgan, J., and Oseroff, A.R. 2001. Mitochondriabased photodynamic anti-cancer therapy. Adv. Drug Deliv. Rev. 49:71-86.

79. Belzacq, A.S., et al. 2001. Apoptosis induction by the photosensitizer verteporfin: identification of mitochondrial adenine nucleotide translocator as a critical target. Cancer Res. 61:1260-1264.

80. Brown, S.B., Brown, E.A., and Walker, I. 2004. The present and future role of photodynamic therapy in cancer treatment. Lancet Oncol. 5:497-508.

81. Zhang, T.D., et al. 2001. Arsenic trioxide, a therapeutic agent for APL. Oncogene. 20:7146-7153.

82. Grad, J.M., et al. 2001. Ascorbic acid enhances arsenic trioxide-induced cytotoxicity in multiple myeloma cells. Blood. 98:805-813.

83. Sordet, O., et al. 2001. Mitochondria-targeting drugs arsenic trioxide and lonidamine bypass the resistance of TPA-differentiated leukemic cells to apoptosis. Blood. 97:3931-3940.

84. Belzacq, A.S., et al. 2001. Adenine nucleotide translocator mediates the mitochondrial membrane permeabilization induced by lonidamine, arsenite and CD437. Oncogene. 20:7579-7587.

85. Di Cosimo, S., et al. 2003. Lonidamine: efficacy and safety in clinical trials for the treatment of solid tumors [review]. Drugs Today (Barc.). 39:157-174.

86. Oudard, S., et al. 2003. Phase II study of lonidamine and diazepam in the treatment of recurrent glioblastoma multiforme. J. Neurooncol. 63:81-86.

87. Don, A.S., et al. 2003. A peptide trivalent arsenical inhibits tumor angiogenesis by perturbing mitochondrial function in angiogenic endothelial cells. Cancer Cell. 3:497-509.

88. Pisha, E., et al. 1995. Discovery of betulinic acid as a selective inhibitor of human melanoma that functions by induction of apoptosis. Nat. Med. 1:1046-1051

89. Fulda, S., Susin, S.A., Kroemer, G., and Debatin, K.M. 1998. Molecular ordering of apoptosis induced by anticancer drugs in neuroblastoma cells. Cancer Res. 58:4453-4460.

90. Fulda, S., and Debatin, K.M. 2000. Betulinic acid induces apoptosis through a direct effect on mitochondria in neuroectodermal tumors. Med. Pediatr. Oncol. 35:616-618.

91. Thurnher, D., et al. 2003. Betulinic acid: a new cytotoxic compound against malignant head and neck cancer cells. Head Neck. 25:732-740.

92. Fulda, S., Jeremias, I., and Debatin, K.M. 2004. Cooperation of betulinic acid and TRAIL to induce apoptosis in tumor cells. Oncogene. 23:7611-7620.

93. Hirsch, T., et al. 1998. PK11195, a ligand of the mitochondrial benzodiazepine receptor, facilitates the induction of apoptosis and reverses Bcl-2-mediated cytoprotection. Exp. Cell Res. 241:426-434.

94. Banker, D.E., et al. 2002. PK11195, a peripheral benzodiazepine receptor ligand, chemosensitizes acute myeloid leukemia cells to relevant therapeutic agents by more than one mechanism. Leuk. Res. 26:91-106.

95. Decaudin, D., et al. 2002. Peripheral benzodiazepine receptor ligands reverse apoptosis resistance of cancer cells in vitro and in vivo. Cancer Res. 62:1388-1393.

96. Marczin, N., El-Habashi, N., Hoare, G.S., Bundy, R.E., and Yacoub, M. 2003. Antioxidants in myocardial ischemia-reperfusion injury: therapeutic potential and basic mechanisms. Arch. Biochem. Biophys. 420:222-236.

97. Chen, Z., et al. 1998. Overexpression of MnSOD protects against myocardial ischemia/reperfusion injury in transgenic mice. J. Mol. Cell. Cardiol. 30:2281-2289.

98. Yoshimoto, T., Uchino, H., He, Q.P., Li, P.A., and Siesjo, B.K. 2001. Cyclosporin A, but not FK506, prevents the downregulation of phosphorylated Akt after transient focal ischemia in the rat. Brain Res. 899:148-158.

99. Matsumoto, S., Isshiki, A., Watanabe, Y., and Wieloch, T. 2002. Restricted clinical efficacy of cyclosporin A on rat transient middle cerebral artery occlusion. Life Sci. 72:591-600.

100.Waldmeier, P.C., Feldtrauer, J.J., Qian, T., and Lemasters, J.J. 2002. Inhibition of the mitochondrial permeability transition by the nonimmunosuppressive cyclosporin derivative NIM811. Mol. Pharmacol. 62:22-29.
101.Serkova, N.J., Christians, U., and Benet, L.Z. 2004. Biochemical mechanisms of cyclosporine neurotoxicity. Mol. Interv. 4:97-107.

102. Niemann, C.U., et al. 2002. Close association between the reduction in myocardial energy metabolism and infarct size: dose-response assessment of cyclosporine. J. Pharmacol. Exp. Ther. 302:1123-1128.

103.Jacotot, E., et al. 2001. Control of mitochondrial membrane permeabilization by adenine nucleotide translocator interacting with HIV-1 viral protein $\mathrm{rR}$ and Bcl-2.J. Exp. Med. 193:509-519.

104.Phenix, B.N., Lum, J.J., Nie, Z., Sanchez-Dardon, J., and Badley, A.D. 2001. Antiapoptotic mechanism of HIV protease inhibitors: preventing mitochondrial transmembrane potential loss. Blood. 98:1078-1085.

105. Wang, J.L., et al. 2000. Structure-based discovery of an organic compound that binds Bcl-2 protein and induces apoptosis of tumor cells. Proc. Natl. Acad. Sci. U. S. A. 97:7124-7129.

106. Tzung, S.P., et al. 2001. Antimycin A mimics a celldeath-inducing Bcl-2 homology domain 3. Nat. Cell Biol. 3:183-191.

107. Degterev, A., et al. 2001. Identification of smallmolecule inhibitors of interaction between the BH3 domain and Bcl-xL. Nat. Cell Biol. 3:173-182.

108. Oltersdorf, T., et al. 2005. An inhibitor of Bcl-2 family proteins induces regression of solid tumors. Nature. 435:677-681.

109.Holinger, E.P., Chittenden, T., and Lutz, R.J. 1999. Bak $\mathrm{BH} 3$ peptides antagonize $\mathrm{Bcl}-\mathrm{xL}$ function and induce apoptosis through cytochrome cindependent activation of caspases. J. Biol. Chem. 274:13298-13304.

110. Walensky, L.D., et al. 2004. Activation of apoptosis in vivo by a hydrocarbon-stapled BH3 helix. Science. 305:1466-1470.

111.Lin, B., et al. 2004. Conversion of Bcl-2 from protector to killer by interaction with nuclear orphan receptor Nur77/TR3. Cell. 116:527-540.

112. Rodi, D.J., et al. 1999. Screening of a library of phage-displayed peptides identifies human bcl-2 as a taxol-binding protein. J. Mol. Biol. 285:197-203.

113. Deverman, B.E., et al. 2002. Bcl-xL deamidation is a critical switch in the regulation of the response to DNA damage. Cell. 111:51-62.

114. Waters, J.S., et al. 2000. Phase I clinical and pharmacokinetic study of bcl-2 antisense oligonucleotide therapy in patients with non-Hodgkin's lymphoma. J. Clin. Oncol. 18:1812-1823.

115.Chi, K.N., et al. 2001. A phase I dose-finding study of combined treatment with an antisense Bcl-2 oligonucleotide (Genasense) and mitoxantrone in patients with metastatic hormone-refractory prostate cancer. Clin. Cancer Res. 7:3920-3927.

116. Egle, A., Harris, A.W., Bouillet, P., and Cory, S. 2004. $\mathrm{Bim}$ is a suppressor of Myc-induced mouse B cell leukemia. Proc. Natl. Acad. Sci. U. S. A. 101:6164-6169.

117.Letai, A., Sorcinelli, M.D., Beard, C., and Korsmeyer, S.J. 2004. Antiapoptotic BCL-2 is required for maintenance of a model leukemia. Cancer Cell. 6:241-249.

118.Tan, T.-T., et al. 2005. Key roles of BIM-driven apoptosis in epithelial tumors and rational chemotherapy. Cancer Cell. 7:227-238. 